\title{
Ridding Hybridoma Cells of Mycoplasma Contamination
}

\author{
Edward A. Greenfield
}

Resistance to the most common antibiotics is what makes elimination of mycoplasma contamination so difficult, but not impossible. Different species of Mycoplasma have varied sensitivities to each of the major classes of antibiotics. One method presented here entails selection in antibiotic-containing medium combined with single-cell cloning over activated macrophage feeders. Its success rate is as high as $70 \%$. As a method of last resort, growing hybridoma cells as ascites tumors is one of the most effective methods of removing mycoplasma contamination. The mycoplasmas are removed from the hybridoma cell surface by the immune system of the mouse. Mice must be of the same genetic background as the hybridomas. This technique is the same as the method for ridding cells of bacterial or fungal infection, and the success rate is perhaps $80 \%$.

It is essential that you consult the appropriate Material Safety Data Sheets and your institution's Environmental Health and Safety Office for proper handling of equipment and hazardous materials used in this protocol.

Reagents

Cell cultures of interest

Lincomycin

Mice

Phosphate-buffered saline (PBS)

Reagents for passaging cells through mice

Culture medium supplemented with $10 \%$ fetal bovine serum

Incomplete Freund's adjuvant

Mice, female, from the same genetic background as the hybridoma

Pristane

Sodium thioglycolate

Tissue culture medium

Tylosin

Equipment

$\mathrm{CO}_{2}$ incubator

Needle (19 gauge), attached to syringe ( $5 \mathrm{~mL}$ )

Plates (24 well)

Plates (96 well)

From the Antibodies collection, edited by Edward A. Greenfield.

(C) 2021 Cold Spring Harbor Laboratory Press

Cite this protocol as Cold Spring Harb Protoc; doi:10.1101/pdb.prot103291 
E.A. Greenfield

Polypropylene centrifuge tubes

Tissue culture dishes $(60$ and $100 \mathrm{~mm})$

\section{METHOD}

\section{Ridding Cells of Mycoplasma Using Antibiotics and Single-Cell Cloning}

1. Remove $\sim 10^{5}$ contaminated cells from culture. Centrifuge the cells at $400 \mathrm{~g}$ for $10 \mathrm{~min}$. Cells can be trypsinized at this step to help remove mycoplasma from the cell membranes.

2. Resuspend the cell pellet in $10 \mathrm{~mL}$ of fresh medium supplemented with $50 \mu \mathrm{g} / \mathrm{mL}$ lincomycin and $10 \mu \mathrm{g} / \mathrm{mL}$ tylosin. Transfer the cells to a fresh tissue culture dish.

3. Culture the cells in medium supplemented with lincomycin and tylosin for $\sim 3 \mathrm{wk}$.

4. One day before setting up the single-cell cloning, begin the preparation of peritoneal macrophage feeders. Inject $0.5 \mathrm{~mL}$ of $0.5 \%$ sodium thioglycolate in PBS intraperitoneally into several mice.

5. On the day of the single-cell cloning, inject $5.0 \mathrm{~mL}$ of PBS intraperitoneally into the thioglycolateprimed mice. Massage each mouse's abdomen with your finger for $\sim 15 \mathrm{sec}$, and remove as much of the peritoneal fluid as possible with a 19-gauge needle attached to a 5-mL syringe. Combine with the fluid from all of the mice in a sterile polypropylene centrifuge tube.

This fluid is rich in peritoneal macrophages.

6. Wash the macrophages from Step 5 once by centrifugation at $400 \mathrm{~g}$ for $10 \mathrm{~min}$ and resuspend them in PBS. During the wash, count a sample of the cells (see Protocol: Counting and Checking the Viability of Myeloma or Hybridoma Cells [Greenfield 2019]). After the last wash, prepare a cell suspension of $5 \times 10^{5}$ macrophages $/ \mathrm{mL}$ in standard tissue culture medium supplemented with lincomycin and tylosin. Plate $100 \mu \mathrm{L}$ of the cell suspension in each well of a 96-well tissue culture plate. Return these plates to the $\mathrm{CO}_{2}$ incubator to allow the $\mathrm{pH}$ to readjust.

These will be the macrophage feeder layer plates on which the hybridoma cells will be plated in the next step.

7. Single-cell-clone the contaminated hybridoma cells over the macrophage feeder cells.

8. Beginning $\sim 7-10 \mathrm{~d}$ after the single-cell cloning, colonies will be visible. Pick several from the lowest dilutions that show any growth. Transfer these to 24-well plates and then expand to 60and 100-mm tissue culture dishes. Keep the cells in the standard tissue culture medium supplemented with lincomycin and tylosin.

9. After the cells have been expanded to the 100-mm-dish stage, split the cultures in half. Transfer one-half to medium without lincomycin and tylosin, and keep the other half in the drug selection. Grow both of these cultures for $2 \mathrm{wk}$ without the drugs and retest for mycoplasma contamination in the culture without antibiotics (see Protocol: Testing Hybridoma Cells for Mycoplasma Contamination [Greenfield 2021]). If the test proves negative, continue to handle as for normal hybridoma or myeloma cultures but check periodically for mycoplasma. If positive, repeat the procedure using the culture until grown in the presence of the antibiotic, but use different antibiotics, or try passing the cells through mice (Steps 10-14).

See Troubleshooting.

Ridding Cells of Mycoplasma by Passage through Mice

This technique has worked with the contents of a single microwell. Therefore, it can be used to rescue a relatively small culture. It may be necessary to single-cell-clone immediately after collecting the ascites.

If the cells form a solid ascitic tumor rather than a loose pocket of cells, it is still possible to rescue the cell line using this technique. Cells quickly grow out of tumor fragments dispersed in tissue culture medium. 
10. Inject $10^{7}$ (or less) cells into female mice that have been injected intraperitoneally $\sim 1$ wk earlier with $0.5 \mathrm{~mL}$ of pristane. These types of injections are also used to prime mice for ascites production, and this may serve as a convenient source of appropriate hosts. If pristane is unavailable, inject mice with Incomplete Freund's adjuvant and wait $4 \mathrm{~h}$ to $1 \mathrm{~d}$ before injecting the hybridoma cells. The animals must be of the same genetic background as your cell line.

When mice are injected with contaminated hybridoma cells, they should be isolated from the remainder of the mouse colony to lessen the chances of infecting the other mice.

See Troubleshooting.

11. If an ascites develops, tap the fluid and transfer it into a sterile centrifuge tube. See Troubleshooting.

12. Centrifuge the ascites at $400 \mathrm{~g}$ for $5 \mathrm{~min}$ at room temperature.

13. Remove the supernatant. Resuspend the cell pellet in $10 \mathrm{~mL}$ of medium supplemented with $10 \%$ fetal bovine serum, and transfer it to a tissue culture plate. The supernatant can be checked for the presence of the antibody and used for further work if needed.

See Troubleshooting.

14. Handle as for normal hybridomas, except keep the cells separate from the other cultures until there is little chance of the contamination reappearing.

Cells recovered from the ascites should be rescreened using one of the techniques described in Protocol: Testing Hybridoma Cells for Mycoplasma Contamination (Greenfield 2021).

Problem (Step 9): Cells are still mycoplasma-positive after treatment.

Solution: It may take a few treatments to eradicate the mycoplasma. Different strains of Mycoplasma have varying susceptibility to different antibiotics. It might be necessary to cycle through a few different antibiotics like the BM Cyclin Mycoplasma Removal Kit (Boehringer Mannheim) does. Passaging the cells through a mouse (Steps 10-14) is another option.

Problem (Step 10): The mice get sick and/or die.

Solution: The bacterial load may be too high, or the animal may be susceptible to that microorganism. Treat the mice with antibiotics in their water. The staff veterinarian should be able to recommend which one and the dosage.

Problem (Step 11): Little to no ascites was produced.

Solution: There may be an MHC mismatch between the strain of mouse and the hybridoma cells. Most myeloma partner cells are BALB/c origin $\left(H-2^{\mathrm{d}}\right)$. If fused with a BALB/c splenocyte, then the hybridoma can be implanted into an BALB/c mouse or another strain that is $\mathrm{H}-2^{\mathrm{d}}$. If the splenocytes originate from a non- $\mathrm{H}-2^{\mathrm{d}}$ mouse strain, then you need to use either nude, SCID, or $\mathrm{F}_{1}$ generation mice made from a cross of a $\mathrm{BALB} / \mathrm{c}$ mouse and the strain that donated the splenocytes.

If the hybridoma is not secreting antibody, ascites will not be produced. Check the cells before implantation for activity.

Problem (Step 13): None of the recovered cells are secreting antibody that recognizes the correct antigen.

Solution: The hybridoma may have been unstable and lost the ability to make the antibody. Check cells before implantation for activity. 
Early work suggested that some mycoplasmas are particularly sensitive to heat; thus, several researchers heat-shock their cells $\left(41^{\circ} \mathrm{C}\right)$ for $18 \mathrm{~h}$ during the early stages of drug selection. Other investigators prefer to grow contaminated cells in the presence of anti-mycoplasma antibodies. These sera can be purchased commercially and should be added to medium prepared with non-heat-inactivated sera, because the killing is primarily performed by complement-mediated lysis. This treatment should not be used in place of drugs or single-cell cloning over macrophage feeders, but as an addition to these treatments. Grow the contaminated cultures in anti-mycoplasma sera during the 2 or 3 wk before the single-cell cloning. During single-cell cloning, the binding of antibodies to the mycoplasma will also increase phagocytosis by the macrophages.

Commercial kits and reagents are available for mycoplasma removal. Follow the protocols recommended by the manufacturers. It is often necessary to use a combination of reagents from different manufacturers to achieve success. Commercial companies also offer cell line cleanup as a service. This service is often very expensive and cannot provide a guarantee of success.

\section{REFERENCES}

Greenfield EA. 2019. Counting and checking the viability of myeloma or hybridoma cells. Cold Spring Harb Protoc doi: 10.1101/pdb.prot103259.
Greenfield EA. 2021. Testing hybridoma cells for Mycoplasma contamination. Cold Spring Harb Protoc doi: 10.1101/pdb.prot103283. 


\section{Ridding Hybridoma Cells of Mycoplasma Contamination}

Edward A. Greenfield

Cold Spring Harb Protoc; doi: 10.1101/pdb.prot103291

\begin{tabular}{|c|c|}
\hline $\begin{array}{r}\text { Email Alerting } \\
\text { Service }\end{array}$ & Receive free email alerts when new articles cite this article - click here. \\
\hline $\begin{array}{l}\text { Subject } \\
\text { Categories }\end{array}$ & $\begin{array}{l}\text { Browse articles on similar topics from Cold Spring Harbor Protocols. } \\
\text { Cell Culture ( } 301 \text { articles) } \\
\text { Generating Antibodies ( } 71 \text { articles) } \\
\text { Generating Antibodies, general (60 articles) } \\
\text { Hybridomas and Myelomas ( } 38 \text { articles) } \\
\text { Monoclonal Antibodies ( } 32 \text { articles) } \\
\text { Mouse (437 articles) }\end{array}$ \\
\hline
\end{tabular}

